\title{
Are salty liquid food flavorings in vitro antitumor substances?
}

\author{
FRANCISCO R.S. CARVALHO ${ }^{1}$, ANTONIO G. MOURA ${ }^{1}$, GARDENIA F. RODRIGUES ${ }^{1}$, \\ NARCIA M.F. NUNES ${ }^{2}$, DAISY J.B. LIMA ${ }^{3}$, CLAUDIA PESSOA ${ }^{3}$, MARCILIA \\ P. COSTA ${ }^{2,4}$, PAULO M.P. FERREIRA ${ }^{2,5}$ and ANA PAULA PERON ${ }^{1}$ \\ ${ }^{1}$ Departamento de Ciências Biológicas, Campus Senador Helvídio Nunes de Barros, Universidade \\ Federal do Piauí, Rua Cícero Duarte, 905, 64607-670 Picos, PI, Brasil \\ ${ }^{2}$ Programa de Pós-Graduação em Ciências Farmacêuticas, Universidade Federal do Piauí, \\ Avenida Universitária, lado ímpar, 64049-550 Teresina, PI, Brasil \\ ${ }^{3}$ Departamento de Fisiologia e Farmacologia, Universidade Federal do Ceará, Rua \\ Coronel Nunes de Melo, 1127, 60430-270 Fortaleza, CE, Brasil \\ ${ }^{4}$ Departamento de Farmácia, Universidade Federal do Piauí, Avenida Universitária, lado ímpar, 64049-550 Teresina, PI, Brasil \\ ${ }^{5}$ Departamento de Biofísica e Fisiologia, Laboratório de Cancerologia Experimental, Universidade \\ Federal do Piauí, Avenida Universitária, lado ímpar, 64049-550 Teresina, PI, Brasil
}

Manuscript received on August 10, 2015; accepted for publication on October 20, 2015

\begin{abstract}
The objective of this study was to evaluate the antiproliferative, cytotoxic and genotoxic potential of salty liquid synthetic flavorings of Butter, Cheddar Cheese and Onion. The antiproliferative potential (2.9$1500 \mu \mathrm{g} / \mathrm{mL}$ ) was assessed by MTT assay after 72h using the human tumor lines SF-295 (glioblastoma), OVCAR-8 (ovarian), HCT-116 (colon) and HL-60 (promyelocytic leukemia) and primary cultures of murine Sarcoma 180 (S180) and peripheral blood mononuclear cells (PBMC). Allium cepa bulbs were exposed to growing respective doses $(1 \mathrm{~mL}$ and $2 \mathrm{~mL})$. Only Butter and Cheddar flavorings revealed cytotoxic activity on cancer cells, with $\mathrm{IC}_{50}$ values ranging from $125.4 \mu \mathrm{g} / \mathrm{mL}$ (Cheddar - HCT-116) to $402.6 \mu \mathrm{g} / \mathrm{mL}$ (Butter - OVCAR-8). Butter flavoring was the most cytotoxic on PBMC $(136.3 \mu \mathrm{g} / \mathrm{mL}$ ) and increased cell division rate in relation to the mitotic index but did not cause cellular aberrations. Onion and Cheddar flavorings reduced the mitotic index after $24 \mathrm{~h}$ and $48 \mathrm{~h}$ exposure, but only Onion flavoring resulted in cellular aberrations and mitotic spindle abnormalities, such as anaphase and telophase bridges, micronucleated cells, conchicine-metaphases and amplifications. So, Butter, Onion and/or Cheddar flavorings caused significant changes in the division of meristematic cells of $A$. cepa and presented cytotoxic action even on decontrolled proliferating human tumor cells.
\end{abstract}

Key words: food additives, Allium cepa, antiproliferative action, neoplasic cells, toxicity.

\section{INTRODUCTION}

Food additives are compounds intentionally added, with no nutritional benefit, aiming to modify the physical, chemical, biological or sensory characteristics of food products. Among these, flavoring

Correspondence to: Ana Paula Peron

E-mail: anpapegenpes@hotmail.com substances are compounds with sensory properties that provide flavor and aroma to various types of foods (Constant et al. 2007). They have complex chemical formulation including diluents, antioxidants, defoamers, preservatives, emulsifiers, stabilizers, acidity regulators, flavor enhancers, antiwetting agents, anti-caking agents, dyes, solvents for 
extraction and processing, approved by the European Food Safety Authority (EFSA) and, nationally, by the Brazilian National Health Surveillance Agency (Agência Nacional de Vigilância Sanitária - ANVISA).

Flavorings are considered a controversial progress of the food industry, once many health experts suggest that these additives, as well as food dyes, contribute significantly to impaired diet and for the triggering of pathologies (Cheeseman 2012). In this way, researchers report that the use of flavoring substances, mainly the synthetic ones, raises a number of questions regarding their toxicity in systemic and cellular level, and point out the urgent need for studies assessing the toxic potential of food flavoring (Wrolstad and Culver 2012). ANVISA (2007) states as constant and priority the improvement of safety on the use of additives in food formulation.

In this context, cytotoxic methods revolutionized cell-based drug screening by offering a highthroughput screening colorimetric assay, whereas they simplified sample processing which requires no radioisotope but they are sensitive enough for miniaturization into 96-well plate formats, as seen in MTT, ATP and Alamar Blue ${ }^{\mathrm{TM}}$ assays. These methods have been very used in the search for new substances with antiproliferative activity and toxic potencial (Skehan et al. 1990, Al-Nasiry et al. 2007, Leite et al. 2014, Ferreira et al. 2015, Monção et al. 2015).

Plant bioassays have been considered highly sensitive and simple in monitoring the cytotoxic and genotoxic effects of chemical compounds (USEPA) (Iganci et al. 2006). Allium cepa L. (onion), through the meristematic regions of roots, has been indicated as an effective test organism for evaluating the toxicity at the cellular level (Caritá and Marin-Morales 2008). This test system has excellent kinetic properties of proliferation and large and few chromosomes $(2 \mathrm{n}=16)$, which facilitates detection of cellular aberrations (Herrero et al. 2012). It also allows verifying changes in cell divi- sion (mitotic index), such as increased or decreased cell proliferation rates in tissues exposed to chemicals of interest (Tabrez et al. 2011).

In the context, this study evaluated the cytotoxicity and genotoxicity of synthetic food flavorings of butter, onion and cheddar on vegetal normal and human and murine tumor cells. These flavorings were chosen because of their wide use as additives by the food industry, especially in the production of frozen foods, and due to their elevated consumption by the population.

\section{MATERIALS AND METHODS}

\section{CHEMICALS}

Salty liquid synthetic flavorings of butter, cheddar cheese and onion, identical to natural, were purchased from a specialized retailer in the national and international marketing of synthetic food additives located in northeastern Brazil. Flavorings, with oily appearance, were packed in amber bottle with a capacity of $100 \mathrm{~mL}$. Doxorubicin and Alamar Blue $^{\text {TM }}$ (Resazurin) were purchased from Sigma Aldrich Co. (St Louis, MO, USA). All flavorings were diluted in dimethylsulfoxide (DMSO) to a final concentration of $50 \mathrm{mg} / \mathrm{mL}$ (stock solution).

In vitro ANTIPROLIFERATIVE ASSAYS

The antiproliferative potential of the salty liquid synthetic flavorings was assessed after $72 \mathrm{~h}$ exposure using the human lines SF-295 (glioblastoma), OVCAR-8 (ovarian carcinoma), HCT-116 (colon carcinoma) and HL-60 (promyelocytic leukemia) and primary cultures of murine Sarcoma 180 (S180) cells and of human peripheral blood mononuclear cells (PBMC).

Cell culture was performed in plastic culture flasks (Corning, $25 \mathrm{~cm}^{2}, 50 \mathrm{~mL}$ volume for adherent cells and $75 \mathrm{~cm}^{2}, 250 \mathrm{~mL}$ volume for cell suspension) using the RPMI 1640 culture medium supplemented with $10 \%$ fetal bovine serum, $2 \mathrm{mM}$ glutamine, $100 \mathrm{U} / \mathrm{mL}$ penincillin and $100 \mu \mathrm{g} / \mathrm{mL}$ streptomycin, at $37{ }^{\circ} \mathrm{C}$ with $5 \% \mathrm{CO}_{2}$. 
Quantification of cell proliferation of the flavorings $(2.9-1500 \mu \mathrm{g} / \mathrm{mL})$ was spectrophotometrically determined using a multiplate reader (DTX 880 Multimode Detector, Beckman Coulter) at a wavelength of $595 \mathrm{~nm}$ for MTT assay and at wavelengths of 570 and $595 \mathrm{~nm}$ in Alamar Blue assays. Control groups (negative and positive) received the same amount of DMSO (0.1\%). Doxorubicin was used as positive control (0.005-5.0 $\mu \mathrm{g} / \mathrm{mL})$.

Cytotoxic activity evaluation against human tumor cell lines

The cytotoxicity of the flavorings against different histological types of human cancer was assessed using the MTT method (Mosmann 1983), which analyzes the ability of living cells to reduce the yellow dye 3-(4,5-dimethyl-2-thiazolyl)-2,5diphenyl- $2 H$-tetrazolium bromide (MTT) to a purple formazan product. Briefly, cells were plated in 96-well plates $\left(0.3-0.7 \times 10^{5}\right.$ cells/well) and incubated to allow cell adhesion. After $24 \mathrm{~h}$ of incubation, the substances previously dissolved in pure, sterile DMSO were added to the plates (2.9$1500 \mu \mathrm{g} / \mathrm{mL}$ ).

After $69 \mathrm{~h}$ of incubation, plates were removed and centrifuged at $1500 \mathrm{rpm}$ for $15 \mathrm{~min}$. The supernatant was aspirated and $200 \mu \mathrm{L}$ of $10 \%$ MTT solution in RPMI 1640 were added; the plate was then incubated at $5 \% \mathrm{CO}_{2}$ for $3 \mathrm{~h}$. Next, plates were again centrifuged, the supernatant was aspirated and the precipitate was resuspended in $150 \mu \mathrm{L}$ pure DMSO and stirred for about 10 min until complete dissolution of the formazan crystals. The reading was performed using a plate spectrophotometer (DTX 880 Multimode Detector, Beckman Coulter) at a wavelength of $595 \mathrm{~nm}$.

\section{In vitro evaluation on the murine Sarcoma 180 tumor}

Adult female Swiss mice (Mus musculus Linnaeus, 1758) were obtained from the animal facilities of the Universidade Federal do Piauí (UFPI), Teresina, Brazil. They were kept in well-ventilated cages under standard conditions of light (12h with alternate day and night cycles) and temperature $\left(27 \pm 2{ }^{\circ} \mathrm{C}\right)$ and were housed with free access to commercial rodent stock diet (Nutrilabor, Campinas, Brazil).

S180 tumor cells are kept in the peritoneal cavities of Swiss mice in the Laboratory of Experimental Oncology of the Federal University of Ceará since the mid 1980s and a tumor sample was recently donated for our laboratory at UFPI. All procedures were approved by the Committee on Animal Research at the UFPI (Process $n^{\circ}$ 008/2015) and followed the Brazilian (Colégio Brasileiro de Experimentação Animal - COBEA) and International Standards on the care and use of experimental animals (Directive 2010/63/EU of the European Parliament and of the Council).

Ascite-bearing mice between 7 and 9 days postinoculation were euthanized by cervical dislocation and a suspension of Sarcoma 180 cells was harvested from the intraperitoneal cavity under aseptic conditions. The suspension was centrifuged at 500 $\mathrm{X} g$ for $5 \mathrm{~min}$ to obtain a cell pellet and washed three times with RPMI medium. Cell concentration was adjusted to $0.5 \times 10^{6}$ cells $/ \mathrm{mL}$ in supplemented RPMI 1640 medium, plated in a 96-well plate and incubated with increasing concentrations of the flavorings [(2.9-1500 $\mu \mathrm{g} / \mathrm{mL})$. Cell proliferation was determined by the Alamar Blue assay after $72 \mathrm{~h}$ of cell culture at $37^{\circ} \mathrm{C}$ with $5 \% \mathrm{CO}_{2}$. Twentyfour hours before the end of incubation, $20 \mu \mathrm{L}$ of stock solution $(0.156 \mathrm{mg} / \mathrm{mL})$ of Alamar Blue ${ }^{\mathrm{TM}}$ were added to each well. The absorbance was measured at $570 \mathrm{~nm}$ and $595 \mathrm{~nm}$ and the drug effect was quantified as the control percentage as described by Ferreira et al. (2011) with one modification, since the measurement was performed after $24 \mathrm{~h}$ following the Alamar Blue addition.

\section{Antiproliferative study on peripheral blood mononuclear cells by Alamar Blue assay}

Heparinized human blood (from healthy, nonsmoker donors who had not taken any drug for 
at least 15 days prior to sampling, aged between 18-35 years-old) was collected and PBMC were isolated by a standard method of density-gradient centrifugation over Ficoll-Hypaque. PBMC were washed and resuspended ( $3 \times 10^{5}$ cells/ $\mathrm{mL}$ ) in supplemented RPMI 1640 medium and phytohemagglutinin (4\%). Then, PBMC were plated in 96-well plates $\left(3 \times 10^{5}\right.$ cells/well). After $24 \mathrm{~h}$, the flavorings were added to each well (2.9$1500 \mu \mathrm{g} / \mathrm{mL}$ ), and the cells were incubated during $72 \mathrm{~h}$. Twenty-four hours before the late incubation, $10 \mu \mathrm{L}$ of stock solution $(0.312 \mathrm{mg} / \mathrm{mL})$ of Alamar Blue ${ }^{\mathrm{TM}}$ were added to each well (Ferreira et al. 2015). The absorbance was measured as described above. All studies were performed in accordance with Brazilian research guidelines (Law 466/2012, National Council of Health, Brazil) and with the Declaration of Helsinki.

EVALUATIONOFTHECYTOTOXICANDGENOTOXICPOTENTIAL IN ROOT MERISTEM CELLS OF Allium cepa

The manufacturing recommendations indicate the use of $1 \mathrm{~mL}$ of flavoring in $300 \mathrm{~g}$ of mass. Thus, test with $A$. cepa were carried out using onion bulbs with an average weight of $300 \mathrm{~g}$ and flavoring doses of 1 and $2 \mathrm{~mL}$.

\section{Root meristem cells for cytogenetic analysis}

Bulbs of A. cepa (onion variety baia) were allowed to root in bottles with distilled water at room temperature $\left( \pm 25^{\circ} \mathrm{C}\right)$, aerated, until obtaining roots of about $2 \mathrm{~cm}$ in length. For analysis of each dose (treatment), an experimental group with five bulbs was established. Before placing the roots in contact with their respective doses, some roots were collected and fixed to work as control of the bulb itself.

The remaining roots of the five bulbs of each dose evaluation were placed in their respective solutions for $24 \mathrm{~h}$, comprising the exposure time of $24 \mathrm{~h}$ ( $24 \mathrm{~h} \mathrm{TE})$. Afterwards, some roots were removed and fixed. The remaining roots of each bulb were returned to their respective solutions and remained for additional $24 \mathrm{~h}$, comprising the exposure time of $48 \mathrm{~h}$ ( $48 \mathrm{~h} \mathrm{TE}$ ). After this period, roots were collected and fixed again. Exposure times of 24 and $48 \mathrm{~h}$ were chosen to evaluate the effects of these doses on more than one cell cycle. All roots were in direct contact with the test solution. Roots were fixed in Carnoy 3: 1 (ethanol: acetic acid) at room temperature for $24 \mathrm{~h}$. For each collection, we took, on average, three roots per bulb.

\section{Preparation and reading of slides}

On average three slides were mounted per bulb, following the method of Guerra and Souza (2002). Each slide was stained with two drops of $2 \%$ acetic orcein and examined under a light microscope with magnification of $400 \mathrm{X}$. A sum of 1,000 cells were analyzed for each bulb, totaling 5,000 cells for each control and treatments.

We analyzed cells in interphase, prophase, metaphase, anaphase and telophase. The number of cells in interphase and in division was calculated for each control and exposure time to determine the mitotic index (MI). The effect of the flavoring doses was also evaluated by the quantification of micronucleated cells, C-metaphases, anaphase and telophase bridges, gene amplification, cells with adhesions, nuclear buds and multipolar anaphase.

\section{STATISTICAL ANALYSIS}

For cytotoxicity assays, the $\mathrm{IC}_{50}$ values and their $95 \%$ confidence intervals were obtained by nonlinear regression using the Graphpad program (Prisma 5.0, Intuitive Software for Science, San Diego, CA). All in vitro studies were carried out in duplicate represented by independent biological evaluations. Outcomes with Allium cepa technique were analyzed by Chi-square test $\left(\chi^{2}\right)$ and differences were considered significant statistically when $\mathrm{p}<0.05$. 


\section{RESULTS AND DISCUSSION}

New perspectives have hardly indicated the need for toxicological and cellular evaluations of flavorings in order to rethink, develop and reorganize, based on the new discoveries, novel technical documents by the regulatory agencies that regulate the use of food additives (Konishi et al. 2011). Firslty, we evaluated the cytotoxic activity of flavoring substances on four tumor cell lines using the MTT test. MTT is a rapid, sensitive, and inexpensive method to analyze the viability and the metabolic state of the cell based on the conversion of the yellow salt MTT into a purple crystal blue by mitochondrial enzymes in metabolically active cells (Skehan et al. 1990) sensitive, and inexpensive method for measuring the cellular protein content of adherent and suspension cultures in 96-well microtiter plates. The method is suitable for ordinary laboratory purposes and for very large-scale applications, such as the National Cancer Institute's diseaseoriented in vitro anticancer-drug discovery screen, which requires the use of several million culture wells per year. Cultures fixed with trichloroacetic acid were stained for 30 minutes with $0.4 \%$ (wt/ vol. As described in table I, only the flavorings of Cheddar and Butter showed cytotoxic activity with $\mathrm{IC}_{50}$ values ranging from $125.4 \mu \mathrm{g} / \mathrm{mL}$ (Cheddar -
HCT-116) to $402.6 \mu \mathrm{g} / \mathrm{mL}$ (Butter - OVCAR-8), although none have revealed cytotoxicity against leukemic cells. It was also verified the antiproliferative action on primary culture of PBMC after $72 \mathrm{~h}$ of incubation. Butter flavoring was the most cytotoxic on human normal proliferating leukocytes [136.3 (111.3-167.0) $\mu \mathrm{g} / \mathrm{mL}]$ (Table I).

In an attempt to envisage an antitumor action upon in vivo assessments, it was determined the activity on Sarcoma 180 cells using the Alamar Blue assay. This metodology incorporates a fluorometric/colorimetric growth indicator based on detection of metabolic activity. Specifically, the system incorporates an oxidation-reduction indicator that both fluoresces and changes color in response to chemical reduction of growth medium resulting from cell growth. This technique has been extensively used to assess different cell types in toxicological, environmental, antimicrobial and cytotoxic susceptibility tests. It presents higher sensibility when compared to other cytotoxicity assays, since smaller amount of cells and steps are required converting it into a suitable method to evaluate proliferation in primary cultures of normal and tumor cells from mice, rats and humans (Gonzales and Tarloff 2001, Al-Nasiry et al. 2007, Rampersad et al. 2012, Schoonen et al. 2012, Bezerra et al. 2015,

TABLE I

In vitro cytotoxic evaluation of the Onion, Cheddar and Butter flavorings on human cancer lines by MTT assay and on primary culture of Sarcoma 180 (S180) cells and peripheral blood mononuclear cells (PBMC) quantified by Alamar Blue assay after $72 \mathrm{~h}$ of incubation.

\begin{tabular}{lcccccc}
\hline \multirow{2}{*}{ Flavoring } & \multicolumn{7}{c}{$\mathbf{I C}_{\mathbf{5 0}}(\boldsymbol{\mu \mathbf { g }} / \mathbf{m L}) *$} \\
\cline { 2 - 7 } & $\mathbf{S F - 2 9 5}$ & $\mathbf{O V C A R - 8}$ & HL-60 & HCT-116 & S180 & PBMC \\
\hline Onion & $>1500$ & $>1500$ & $>1500$ & $>1500$ & $>1500$ & $>1500$ \\
\hline \multirow{2}{*}{ Cheddar } & 301.8 & 385.8 & $>1500$ & 125.4 & $>1500$ & $>1500$ \\
\hline \multirow{2}{*}{ Butter } & $248.3-366.8$ & $332.3-448.2$ & & $102.1-154.0$ & & 136.3 \\
& 402.6 & 383.2 & $>1500$ & $194.1-323.9$ & $>1500$ & $(111.3-167.0)$ \\
\hline \multirow{2}{*}{ Doxorubicin } & $0.1-531.3$ & $313.4-468.7$ & & 0.1 & 1.9 & 0.97 \\
& $0.13-0.23$ & $0.17-0.31$ & $0.01-0.02$ & $0.09-0.17$ & $1.4-2.4$ & $0.52-1.80$ \\
\hline
\end{tabular}

*Data are presented as $\mathrm{IC}_{50}$ values and $95 \%$ confidence intervals for leukemia (HL-60), colon (HCT-116), glioblastoma (SF-295) and leukemia (HL-60) human cancer lines and for murine S180 and peripheral blood mononuclear cells. Doxorubicin (Dox) was used as positive control. Experiments were performed in duplicate. 
Ferreira et al. 2015). Herein, we did not found antiproliferative action of the flavorings against these malignant S180 cells, exhibiting negative results as those found with leukemia cells (Table I). In fact, cell type antiproliferative specificity is observed with substances with a pool of chemicals, and this is probably due to the presence of different classes of compounds (Cragg et al. 1994). Hence, the use of more than one cell line is considered necessary for detection of cytotoxic compounds.

Since S180 cells are maintained in peritoneal cavity of mice, it is likely that their behavior are similar to those presented by HL-60 suspended cells. Maybe, flavorings are interfering on tumor adhesion to the extracellular matrix (ECM) (in this case is the plastic flask), which causes cytotoxic action. Adhesion to the ECM is essential for survival and propagation of adherent cells. Loss of adhesion activates apoptosis known as anoikis. Previously, some works with Brefeldin A (BFA), a mycotoxin that causes endoplasmic reticulum stress in eukaryotic cells, preferentially induces cell death in MDA-MB-231 (breast carcinoma) suspension cultures in comparison with adherent cultures (Tseng et al. 2014).
Although in vitro cytotoxicity studies by MTT assay and similar tecniques are effective in finding new substances with antiproliferative potential, they do not determine the mechanism of action (Berridge et al. 1996). To evaluate the action of these three flavorings, we also used root meristem cells of $A$. cepa to achieve more detailed data about their toxicity at the cell level. This test system is widely used in the screening of cytotoxicity and genotoxicity of chemicals (Herrero et al. 2012) and has satisfactory similarity to results with other test organisms (Arung et al. 2011, Gomes et al. 2013, Oliveira et al. 2013).

Table II describes the number of cells in interphase and in different stages of cell division and values of the mitotic index from root meristem A. cepa cells treated with Butter flavoring. There was a significant increase in the rate of cell division in relation to the MI in all doses and times tested in comparison with the control. None of the doses caused cell aberrations or interfered in the MI between $24 \mathrm{~h}$ and $48 \mathrm{~h}$ exposure since mitotic spindle alterations or micronucleus are not observed $(\mathrm{p}>0.05)$.

TABLE II

Total number of cells analyzed on the cell cycle of root tips of Allium cepa treated with 1 and 2 mL of Butter flavoring at exposure times of 24 and $48 \mathrm{~h}$.

\begin{tabular}{ccccccccc}
\hline Dose & ET & Undifferentiated cells/Interphase & $\mathbf{P}$ & $\mathbf{M}$ & $\mathbf{A}$ & $\mathbf{T}$ & Cells in division & MI (\%) \\
\hline \multirow{3}{*}{$1 \mathrm{~mL}$} & $\mathrm{C}$ & 4464 & 202 & 187 & 82 & 65 & 536 & 10.7 \\
& $24 \mathrm{~h}$ & 3711 & 438 & 397 & 301 & 153 & 1289 & $25.8^{*}$ \\
& $48 \mathrm{~h}$ & 3830 & 413 & 389 & 219 & 149 & 1170 & $23.4^{*}$ \\
\hline \multirow{3}{*}{$2 \mathrm{~mL}$} & $\mathrm{C}$ & 4381 & 190 & 177 & 152 & 100 & 619 & 12.4 \\
& $24 \mathrm{~h}$ & 3892 & 345 & 289 & 271 & 203 & 1108 & $22.2^{*}$ \\
& $48 \mathrm{~h}$ & 3830 & 392 & 279 & 298 & 201 & 1170 & $23.4^{*}$ \\
\hline
\end{tabular}

ET - Exposure Time; C - Negative control; MI - Mitotic Index. *Mean values of MI were analyzed by Chi-square test $\left(\chi^{2}\right)$ and were significantly different when $\mathrm{p}<0.05$.

According to Cavalcantti et al. (2012), diacetyl (2,3-butanedione), a diluent at large quantities in the chemical composition of the Butter flavoring, cause obliterative bronchiolitis, a very common disease in workers at microwave popcorn factories, which blocks the bronchioles and compromises lung function. Whittaker et al. (2008) analyzed the mutagenic potential of this chemical compound in a gene mutation assay with rat lymphoma cells (L5178Y line) and observed that diacetyl caused 
significant damage to loci on chromosome 11 of these cells and caused functional loss of the locus for thymidine kinase enzyme, causing uncontrolled proliferation of cells of the cell line used.

High doses of diacetyl are cytotoxic because of its potential to replace thymine with guanine. This change may affect the control of cell division (More et al. 2012), which can explain, at least in part, the increasing in proliferating of the root meristem cells. In fact, some studies state that diacetyl might be considered a tumor activator. Likewise, Potera (2012), in a study with mice, found that diacetyl led to fibroblast proliferation in the lungs of these animals due to increased expression of genes responsible for the production of cytokines. Thus, the results obtained by More et al. (2012) and Potera (2012) confirm the results obtained in this study, when the doses used stimulated a significant increase in cell division.

Table III presents the number of cells in interphase and in different stages of cell division and values of the mitotic index from root meristem A. cepa cells treated with Cheddar flavoring. It was observed that $1 \mathrm{~mL}$ and $2 \mathrm{~mL}$ of Cheddar flavoring caused dose dependent reduction in the mitotic index after $24 \mathrm{~h}$ (15.0 and $6.5 \%)$ and 48h (6.0 and $6.3 \%)$ exposure, respectively $(\mathrm{p}<0.05)$.

Table IV shows the number of cells in interphase and in different stages of cell division and values of the mitotic index from root meristem cells of $A$. cepa treated with Onion flavoring (ET 24 and 48h). This flavoring reduced cell division at 24 or $48 \mathrm{~h}$ exposure for both doses of $1 \mathrm{~mL}(3.5$ and $2.1 \%)$ and $2 \mathrm{~mL}(2.5$ and $2.6 \%)(\mathrm{p}<0.05)$. However, no statistical differences were found between doses ( $p>0.05)$. In both ET and doses, it was noted increase of cells in prophase, especially at ET 48h, suggesting that Onion flavoring in such conditions interfered on formation or configuration of mitotic spindles, but additional studies will be performed to confirm it.

TABLE III

Number of cells analyzed on the cell cycle of root tips Allium cepa treated with 1 and 2 mL of Cheddar flavoring at exposure times of 24 and $48 \mathrm{~h}$.

\begin{tabular}{ccccccccc}
\hline Dose & ET & Undifferentiated cells/Interphase & P & M & A & T & Cells in division & MI (\%) \\
\hline \multirow{3}{*}{$1 \mathrm{~mL}$} & $\mathrm{C}$ & 3541 & 1205 & 116 & 85 & 53 & & 1459 \\
& $24 \mathrm{~h}$ & 4249 & 544 & 107 & 44 & 56 & 751 & 29.2 \\
& $48 \mathrm{~h}$ & 4702 & 114 & 106 & 43 & 35 & 298 & $6.0^{*}$ \\
\hline \multirow{3}{*}{$2 \mathrm{~mL}$} & $\mathrm{C}$ & 3426 & 465 & 55 & 32 & 22 & 1574 & 31.5 \\
& $24 \mathrm{~h}$ & 4777 & 213 & 57 & 31 & 22 & 323 & $6.5^{*}$ \\
& $48 \mathrm{~h}$ & 4685 & 282 & 18 & 07 & 08 & 315 & $6.3 *$ \\
\hline
\end{tabular}

ET - Exposure Time; C - Negative control; MI - Mitotic Index. *Mean values of MI were analyzed by Chi-square test $\left(\chi^{2}\right)$ and were significantly different when $\mathrm{p}<0.05$.

TABLE IV

Total number of cells analyzed on the cell cycle of root tips of Allium cepa treated with 1 and 2 mL of Onion flavoring at exposure times of 24 and $48 \mathrm{~h}$.

\begin{tabular}{ccccccccc}
\hline Dose & ET & Undifferentiated cells /Interphase & P & M & A & T & Cells in division & MI (\%) \\
\hline \multirow{3}{*}{$1 \mathrm{~mL}$} & $\mathrm{C}$ & 4561 & 161 & 105 & 82 & 91 & 439 & 8.8 \\
& $24 \mathrm{~h}$ & 4826 & 129 & 14 & 22 & 09 & 174 & $3.5^{*}$ \\
& $48 \mathrm{~h}$ & 4896 & 101 & 00 & 01 & 02 & 104 & $2.1^{*}$ \\
\hline \multirow{3}{*}{$2 \mathrm{~mL}$} & $\mathrm{C}$ & 4454 & 270 & 86 & 58 & 132 & 546 & 10.9 \\
& $24 \mathrm{~h}$ & 4874 & 101 & 16 & 09 & 00 & 126 & $2.5^{*}$ \\
& $48 \mathrm{~h}$ & 4871 & 124 & 05 & 0 & 00 & 129 & $2.6^{*}$ \\
\hline
\end{tabular}

ET - Exposure Time; C - Negative control; MI - Mitotic Index. *Mean values of MI were analyzed by Chi-square test $\left(\chi^{2}\right)$ and were significantly different when $\mathrm{p}<0.05$. 
In table $\mathrm{V}$, it is also demonstrated that both treatments with Onion flavoring at doses of $1 \mathrm{~mL}$ and $2 \mathrm{~mL}$ reduced the mitotic index (24h: $3.5 \%$, 48h: $2.1 \%$ / 24h: $2.5 \%$, 48h: $2.6 \%$ ) and increased anaphase and telophase bridges (48h: 13 and 24h: 27), micronucleated cells (24h: 113, 48h: 125 / 24h: 175, 48h: 118), C-metaphases (48h: 22 and 33) and amplifications (24h: 67), respectively. So, cellular aberrations [1 mL (24h: 182, 48h: 160); 2 mL (24h: 202, 48h: 153)] were higher when compared to the negative control $(\mathrm{p}<0.05)$ (Fig. 1).

Thus, under these conditions, Onion flavoring revealed cytotoxic activity, as demonstrated by high antiproliferative rates and genotoxicity activity, promoting formation of micronuclei and mitotic spindle abnormalities in the vegetal cells. These results differ from those obtained with in $v i$ tro assays with human and murine cells, on which this food additive was not cytotoxic. There were no studies assessing the toxicity at the cellular level of this food flavoring.

Unfortunately, there are no data about chemical constituents of these flavorings. Some few reports described toxicity studies with compounds also found in additives. Among the flavorings, some of them inhibit microbial proliferation, we can cite potassium benzoate, sodium benzoate and potassium nitrate. They are clastogenic, mutagenic and cytotoxic compounds on normal peripheral human blood cells (Brasil 1999, Mpountoukas et al. 2010, Zequin et al. 2011). Moreover, boric acid, citric acid, potassium citrate and sodium citrate are cytotoxic on meristematic cells of A. cepa (Brasil 1999, Türkoğlu 2007). Benzyl alcohol is frequently used as diluent in foods to maintain uniformity and facilitate incorporation and dispersion of flavors. It was showed that high concentrations of benzyl alcohol promoted significant damage to the mitotic spindle and, therefore, interfered in cell division of human blood cells (Demir et al. 2010). However, these results can not be extrapolated for the present results obtained with flavorings of butter, cheddar cheese, since their ingredients are unclear yet. It is important to emphasize that for each class of aroma and flavor additives, about thirty chemical compounds are represented (ANVISA 2007). Among them, the class with usage restriction of some of its constituents is solvent for extractions, such as agaric acid, aloin, berberine, coumarin, hydrocyanic acid, hypericin, pulegone, safrole and isosafrole, santonin and alpha and beta tuyona that have maximum tolerable limits in food flavorings (Brasil 1999). Moreover, the food flavoring sparteine, allyl hexanoate and quinine were prohibited by these agencies in the early 1980 due to outcomes from evaluation studies of acute and long-term tests carried out in different systems (Konishi et al. 2011).

Recent studies have shown that food flavoring can be highly toxic when used for prolonged peri-

TABLE V

Number of anaphase and telophase bridges, micronucleated cells, colchicine metaphases, amplifications and total number of cellular aberrations in each control and at doses of 1 and $2 \mathrm{~mL}$ of Onion flavoring.

\begin{tabular}{ccccccc}
\hline Dose & ET & $\begin{array}{c}\text { Anaphase and } \\
\text { telophase bridges }\end{array}$ & $\begin{array}{c}\text { Micronucleated } \\
\text { cells }\end{array}$ & C-metaphase & Amplifications & $\begin{array}{c}\text { Total number of } \\
\text { cellular aberrations }\end{array}$ \\
\hline \multirow{3}{*}{$1 \mathrm{~mL}$} & $\mathrm{C}$ & 1 & 0 & 0 & 0 & 01 \\
& $24 \mathrm{~h}$ & 0 & 113 & 2 & 67 & $182^{*}$ \\
\hline \multirow{3}{*}{$2 \mathrm{~mL}$} & $48 \mathrm{~h}$ & 13 & 125 & 22 & 0 & $160^{*}$ \\
\hline
\end{tabular}

ET - Exposure Time; C - Negative control. *Mean values of MI were analyzed by Chi-square test $\left(\chi^{2}\right)$ and were significantly different when $\mathrm{p}<0.05$. 


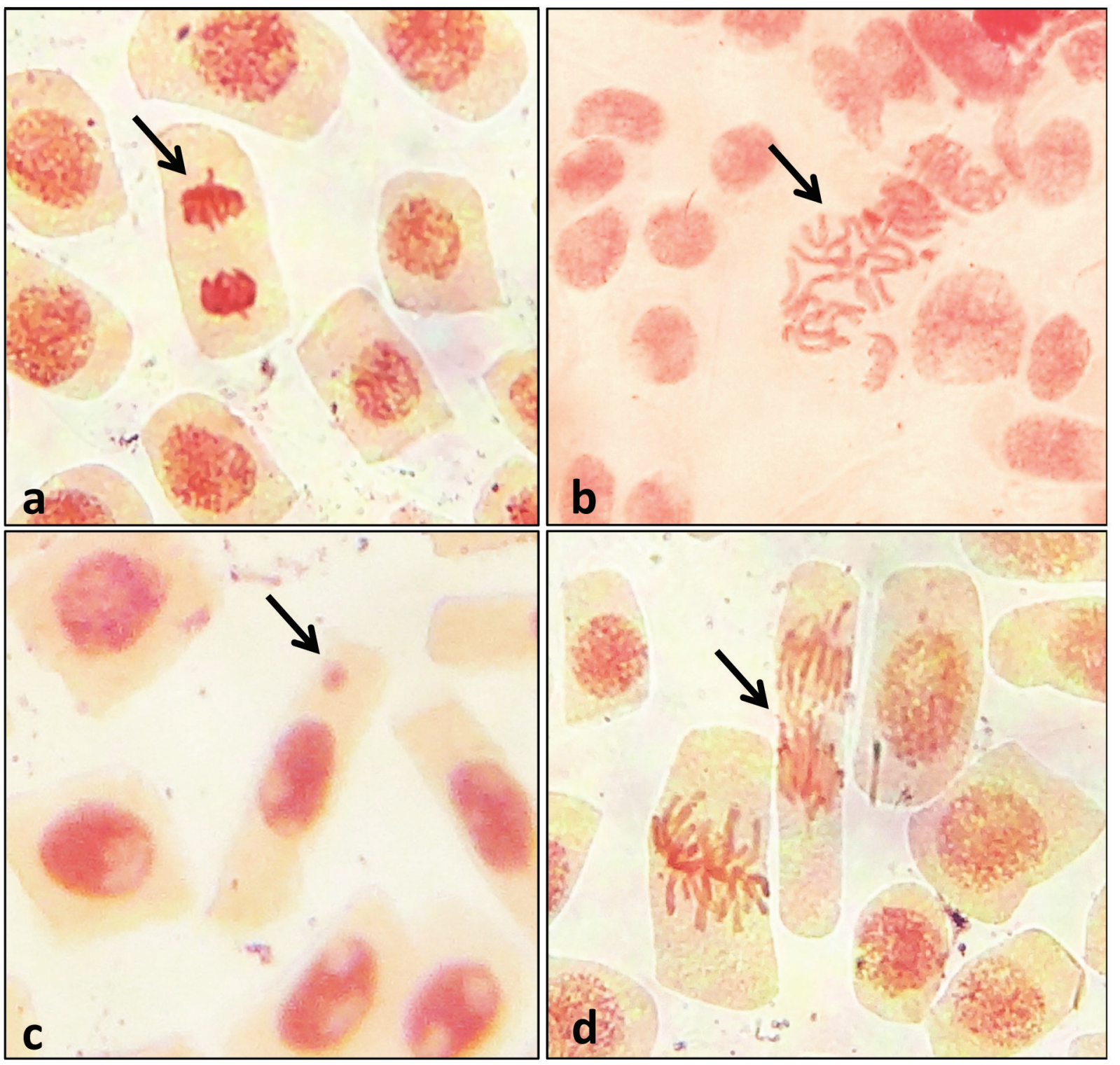

Figure 1 - Cellular aberrations and mitotic spindle abnormalities caused by Onion flavoring on root meristem cells of Allium cepa after $24 \mathrm{~h}$ and/or $48 \mathrm{~h}$ of treatment. a: late anaphase in chromosome; b: metaphase in chromosome not aligned in the equatorial plate; c: micronucleus; d: anaphase bridges. Staining with acetic orcein and examination by light microscope. Magnification, 400X.

ods, promoting hyperactivity in children with and without attention deficit (Stevens et al. 2015), causes blood hemoglobin concentration decreasing, drastic changes in liver function, reduces body weight gain of mice, triggers allergies, skin hypersensitivity and has poor digestion in humans (Anderson et al. 2013, Voltolini et al. 2014). Nevertheless, flavoring additives are poorly studied in the toxicological point of view and a few studies have assessed the toxicity of food flavoring at the cellular level, differently from most of the dyes used in food industry, which have been widely studied in diverse bioassays and have well-defined values of Acceptable Daily Intake (ADI) (Honorato et al. 2013).

In Brazil, ANVISA (2007) states that high doses of flavorings can cause irritant and narcotic 
actions and produce chronic toxicity in digestive tract in the long-term when indiscriminately used. Nevertheless, this regulatory agency as well as EFSA fails to inform the limits of daily intake for these additives and does not report the doses which are considered high nor which flavoring causes cellular or specific organ damage.

Salinas (2002) also believes that food additives have cellular toxicity in the long term. However, similarly to ANVISA (2007), he does not determine which are considered high and low doses, nor define the flavoring causing this type of action. So, although the use of flavoring is permitted by the Ministry of Health and ANVISA, it is necessary and urgent to develop studies to determine the toxic potential and safety doses of these food flavors (Honorato et al. 2013).

\section{CONCLUSIONS}

Butter, Onion and/or Cheddar flavorings caused significant changes in the cell division (and cellular aberrations) of root meristem cells of A. cepa and presented cytotoxic action even on decontrolled proliferating human tumor cells. So, it is important to conduct supplementary bioassays to check on the cellular level how these additives promote cell death in cells from different types of organisms [plant and mammals (mice and humans)]. In vivo toxicological investigations with mammals and further in vitro studies are in progress to detail this mechanism, taking into consideration that balance of matrix metalloproteinases (MMP) production by tumor cells may be damaged and to activate cell death (Kessenbrock et al. 2010).

\section{ACKNOWLEDGMENTS}

We wish to thank Conselho Nacional de Desenvolvimento Científico e Tecnológico (CNPq), Fundação Cearense de Apoio ao Desenvolvimento Científico e Tecnológico (FUNCAP) and Fundação de Amparo à Pesquisa do Estado do Piauí (FAPE-
PI \#034/2012) for financial support in the form of grants and fellowship awards.

\section{REFERENCES}

AL-NASIRY S, GEUSENS N, HANSSENS M, LUYTEN C AND PIJNENBORG R. 2007. The use of Alamar Blue assay for quantitative analysis of viability, migration and invasion of choriocarcinoma cells. Hum Reprod 22: 13041309.

ANDERSON SE, FRANKO J, WELLS JR, LUKOMSKA E AND MEADE BJ. 2013. Evaluation of the hypersensitivity potential of alternative butter flavorings. Food Chem Toxicol 62: 373-381.

ANVISA - AGÊNCIA NACIONAL DE VIGILÂNCIA SANITÁRIA. Resolução da Diretoria Colegiada-RDC No. 05, de 15 de Janeiro de 2007. Disponível em: <http:// www.anvisa.gov.br/legis/resol/2007/rdc/02 170107rdc. pdf>. Acesso em: 08 fev, 2015.

ARUNG ET, FURUTA S, ISHIKAWA H, SHIMIZU K AND KONDO R. 2011. Melanin biosynthesis inhibitory and antioxidant activities of quercetin-3'-O-beta-D-glucose isolated from Allium cepa. Z Naturforsch C 66: 209-214.

BERRIDGE MV, TAN AS, MCCOY KD AND WANG

R. 1996. The biochemical and cellular basis of cell proliferation assays that use tetrazolium salts. Biochemica 4: 14-19.

BEZERRA DP, FERREIRA PMP, MACHADO CL, AQUINO NC, SILVEIRA ER, CHAMMAS R AND PESSOA C. 2015. Antitumour efficacy of Piper tuberculatum and Piplartine based on the Hollow Fiber Assay. Planta Medica 81: 15-19.

BRASIL. 1999. Ministério da Saúde. Agência Nacional de Vigilância Sanitária. Regulamento Técnico sobre Aditivos Aromatizantes/Aroma. Resolução $\mathrm{N}^{0} 104$ de 14 de maio de 1999. Disponível em: $\square$ http://www.engetecno.com. br/port/legislacao/norqual_aditivos_aromatizantes.htm $\square$. Acesso em: 13 abril, 2015.

CARITÁ R AND MARIN-MORALES MA. 2008. Induction of chromosome aberrations in the Allium cepa test system caused by the exposure of seeds to industrial effluents contaminated with azo dyes. Chemosphere 72: 722-725.

CAVALCANTTI ZR, ALBUQUERQUE FILHO APL, PEREIRA CAC AND COLETTA ENAM. 2012. Bronquiolite associada a exposição a aroma artificial de manteiga em trabalhadores de uma fábrica de biscoitos no Brasil. J Bras Pneumol 38: 395-399.

CHEESEMAN MA. 2012. Artificial food color additives and child behavior. Environ Health Perspect 20: 15-16.

CONSTANT PBL, STRINGUETA PC AND SANDI D. 2007. Corantes alimentícios. B CEPPA 20: 203-220.

CRAGG GM, BOYD MR, CARDELLINA JH, NEWMAN DJ, SNADER KM AND MCCLOUD TG. 1994. 
Ethnobotany and drug discovery experience of the US National Cancer Institute. In: Chadwick DJ and Marsh J (Eds), Ciba Foundation Ethnobotany and the search for new drugs. Chichester: J Wiley \& Sons, p. 178-196.

DEMIR E, KOCAOGLU S AND KAYA R. 2010. Assessment genotoxic effects of benzyl derivatives by comet assay. Food Chem Toxicol 48:1239-1242.

FERREIRA PMP ET AL. 2015. Cytotoxic and toxicological effects of phthalimide derivatives on tumor and normal murine cells. An Acad Bras Cienc 87: 313-330.

FERREIRA PMP, FARIAS DF, VIANA MP, SOUZA TM, VASCONCELOS IM, SOARES BM, PESSOA C, COSTA-LOTUFO LV, MORAES MO AND CARVALHO AFU. 2011. Study of the antiproliferative potential of seed extracts from Northeastern Brazilian plants. An Acad Bras Cienc 83: 1045-1058.

GOMES KM, PERON AP, OLIVEIRA MVA AND CARVALHO FRS. 2013. Citotoxicity of food dyes sunset yellow (E-110), bordeaux red (E-123), and tatrazine yellow (E-102) on Allium cepa L. root meristematic cells. Cienc Tecnol Aliment 33: 218-223.

GONZALES RJ AND TARLOFF JB. 2001. Evaluation of hepatic subcellular Alamar bleu and MTT reductase activity. Toxicol in Vitro 15: 257-259.

GUERRA M AND SOUZA MJ. 2002. Como observar os cromossomos: um guia de técnicas em citogenética vegetal, animal e humana. Ribeirão Preto: FUNPEC, 213 p.

HERRERO O, PEREZ JM, FERNANDEZ PF, CARVAJAL LL, PEROPADRE A AND ANDHAZEN MJ. 2012. Toxicological evaluation of three contaminant of emerging concern by use of Allium cepa test. Mut Res 743: 24-34.

HONORATO TC, BASTISTA E, NASCIMENTO KDOD AND PIRES T. 2013. Aditivos alimentares: aplicações e toxicologia. RVADS 8: 1-11.

IGANCI JRV, BOBROWSKI VL, HEIDEN G, STEIN VC AND ROCHA BHG. 2006. Efeito do extrato aquoso de diferentes espécies de boldo sobre a germinação índice mitótico de Allium cepa L. Arq Inst Biol 73: 79-82.

KESSENBROCK K, PLAKS V AND WERB Z. 2010. Matrix Metalloproteinases: Regulators of the Tumor Microenvironment. Cell 141: 52-67.

KONISHI Y, HAYASHI SM AND FUKUSHIMA S. 2011. Regulatory forum opinion piece*: supporting the need for international harmonization of safety assessments for food flavoring substance. Toxicol Pathol 42: 949-953.

LEITE ACL ET AL. 2014. Phthaloyl amino acids as antiinflammatory and immunomodulatory prototypes. Med Chem Res 23: 1701-1708.

MONÇÃO NBN, ARAÚJO BQ, SILVA JN, LIMA DJB, FERREIRA PMP, AIROLD FPS, PESSOA C AND CITÓ AMGL. 2015. Assessing chemical constituents of Mimosa caesalpiniifolia stem bark: possible bioactive components accountable for the cytotoxic effect of $M$. caesalpiniifolia on human tumour cell lines. Molecules 20: 4204-4224.
MORE SC, RAZA A AND VINCE R. 2012. The butter flavorant diacetyl forms a covalent adduct with 2-deoxyguanosine, uncoils DNA and leads to all death. J Agric Food Chem 60: 3311-3317.

MOSMANN T. 1983. Rapid Calorimetric assay for cellular growth and survival application to proliferation and cytotoxicity assay. J Immunol Methods 65: 55-63.

MPOUNTOUKAS P, PANTAZAKI A, KOSTARELI E, CHRISTODOULOU P, KARELI D, POLILIOU S AND LIALIARIS T. 2010. Cytogenetic evaluation and DNA interaction studies of the food colorants amaranth, erythrosine and tartrazine. Food Chem Toxicol 48: 2934-2944.

OLIVEIRA MVA, ALVES DDL, LIMA LHGM, CASTRO JM AND PERON AP. 2013. Citotoxicidade dos corantes alimentares erythrosine (E-127), azul brilhante (E-133) e red 40 (E-129) em sistema-teste vegetal. Acta S Biol Sci 35: $557-562$.

POTERA C. 2012. Food Addtives: still searching for better butter flavoring. Environ Health Perspect 20: 457.

RAMPERSAD SN. 2012. Multiple applications of alamar blue as an indicator of metabolic function and cellular health in cell viability bioassays. Sensors 12: 12347-12360.

SALINAS RD. 2002. Alimentos e Nutrição: Introdução a Bromatologia. Porto Alegre: Artmed, 400 p.

SCHOONEN WG, STEVENSON JC, WESTERINK WM AND HORBACH GJ. 2012. Cytotoxic effects of 109 reference compounds on rat H4IIE and human HepG2 hepatocytes. III: Mechanistic assays on oxygen consumption with MitoXpressTM and NAD(P)H production with Alamar Blue. Toxicol in Vitro 26: 511-525.

SKEHAN P, STORENG R, SCUDIERO D, MONKS A, VISTICA JMD, WARREN JT, BORESCH H, KENNEY S AND BOYD M. 1990. New calorimetric cytotoxicity for anticancerdrug screening. J Natl Cancer Inst 82: 1107-1112.

STEVENS LJ, BURGESS JR, STOCHELSKI MA AND KUCZEK T. 2015. Amounts of artificial food dyes and added sugars in food and sweets commonly consumed. Clin Pediatr 54: 309-321.

TABREZ S, SHAKIL S, UROOJ M, DAMANHOURI GA, ABUZENADAH AM AND ANDAHMAD M. 2011. Genotoxicity testing and biomarker studies on surface water: an over view of the techniques and their efficacies. J Environ Sci Health C Environ Carcinog Ecotoxicol Rev 29: 250-275.

TÜRKOĞLU Ş. 2007. Genotoxicity of five food preservatives tested on root tips of Allium cepa L. Mut Res 626: 4-14.

TSENG CN ET AL. 2014. Brefeldin A reduces anchorageindependent survival, cancer stem cell potential and migration of MDA-MB-231 human breast cancer cells. Molecules 19: 17464-17477.

VOLTOLINI S, PELLEGRINI S, CONTATORE M, BIGNARDI D AND MINALE P. 2014. New risks from 
ancient food dyes: cochineal red allergy. Eur Ann Allergy Clin Immunol 46: 232-233.

WHITTAKER P, CLARKE JJ, SAN RH, BEGLEY TH AND DUNKEL VC. 2008. Evaluation of the butter flavoring chemical diacetyl and a fluorochemical paper additive for mutagenicity and toxicity using the mammalian cell gene mutation assay in L5178Y mouse lymphoma cells. Food Chem Toxicol 46: 2928-2933.
WROLSTAD CA AND CULVER CA. 2012. Alternatives to those artificial FD\&C food colorants. Annu Rev Food Sci Technol 3: 59-77.

ZEQUIN N, YÜZBAŞIOĞLU D, UNAL F, YILMAZ S AND AKSOY H. 2011. The evaluation of the genotoxicity of two food preservatives: sodium benzoate and potassium benzoate. Food Chem Toxicol 49: 763-769. 